\title{
Two new species of Aponogeton (Aponogetonaceae), and a key to species from Australia
}

\author{
Surrey W.L. Jacobs' ${ }^{1}$ Donald H. Les², Michael L. Moody ${ }^{3}$ \\ and C. Barre Hellquist ${ }^{4}$
}

\author{
${ }^{1}$ National Herbarium, Royal Botanic Gardens, Mrs Macquaries Rd, Sydney, NSW 2000, Australia \\ Author for correspondence: surrey.jacobs@rbgsyd.nsw.gov.au \\ ${ }^{2}$ Department of Ecology and Evolutionary Biology, University of Connecticut, \\ Storrs, Connecticut 06269-3043, USA \\ ${ }^{3}$ Indiana University, Department of Biology, Jordan Hall 142, 1001 E. 3rd St., \\ Bloomington, IN 47405, USA \\ ${ }^{4}$ Department of Biology, Massachusetts College of Liberal Arts, North Adams, \\ MA 01247-4100, USA
}

\begin{abstract}
Two new species, Aponogeton cuneatus (removed from A. elongatus) and Aponogeton tofus (removed from A. euryspermus) are described from Australia. A key is provided for all native and naturalised Aponogeton species in Australia, and new descriptions are provided for A. elongatus and A. euryspermus.
\end{abstract}

\section{Introduction}

Hellquist and Jacobs (1998) revised the Australian species of Aponogeton, describing six new taxa. Even though there had been a substantial increase in the number of specimens available for examination since Bruggen's (1969) pioneering work, our paper stimulated further collecting and further good quality specimens have become available. While collecting DNA samples for a phylogenetic study of the family (Les et al. 2005) we observed some material that indicated to us the possibility that there may be at least one additional new species. The results of the analyses in Les et al. (2005) clearly demonstrate that there actually are two new species, one (identified previously as A. elongatus) that molecular data resolved as a distinct sister species to A. queenslandicus, and another (identified previously as A. euryspermus) that resolved as a distinct sister species to the A. euryspermus/A. kimberleyensis clade. Examination of morphological characters has confirmed their status by demonstrating that these species are not only well-defined by their degree of molecular divergence but also are distinctive morphologically. The two new species of Aponogeton are described here, with modified descriptions of the species in which they were formerly included also provided, along with a key to all Australian species. 


\section{Key to native and naturalised species of Aponogeton in Australia}

1. Proliferous offshoots formed at tip of peduncle; plants rarely flowering.

A. proliferus

$1^{\star}$ Proliferous offshoots not formed on plants; plants regularly flowering.

\section{2}

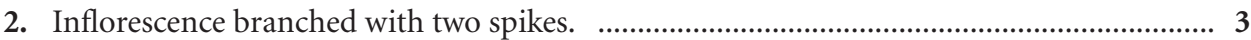

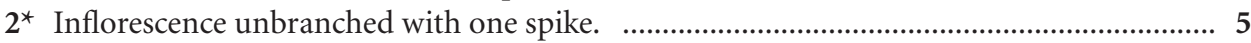

3. Flowers white (rarely pink); tepals 1 , with 13 or more veins.

${ }^{\star}$ A. distachyos

$3^{*}$ Flowers yellow, yellow-green, or green; tepals 2-6, 1-veined.

4

4. Tepals 6; seeds (2.6-)5.1-6.2(-7.0) mm long; leaves all floating.

A. hexatepalus

$4^{*}$ Tepals 2; seeds $2.1-3.2 \mathrm{~mm}$ long; leaves all submersed.

A. lancesmithii

5. Leaves all submersed, slightly to strongly bullate.

$5^{\star}$ Leaves submersed and/or floating, not bullate.

6. Spathe persistent, to $2.5 \mathrm{~cm}$ long; inflorescence to $5.5 \mathrm{~cm}$ long; peduncle about same diameter as inflorescence rachis.

A. bullosus

6* Spathe caducous, to $1.5 \mathrm{~cm}$ long; inflorescence to $34 \mathrm{~cm}$ long; peduncle much broader than inflorescence rachis.

A. lancesmithii

7. Plants mainly producing floating leaves; floating leaves mostly cordate at base; seeds with obvious double testa.

A. queenslandicus

$7^{*}$ Plants mainly producing submersed leaves or submersed and floating leaves; floating leaves mostly obtuse, some cuneate or truncate at base; seeds with a single testa or, if double, the second seed coat closely adhering and difficult to detect.

8

8. Submersed leaves narrow, $0.9-3 \mathrm{~mm}$ wide; seeds $0.7-1.4 \mathrm{~mm}$ long

A. kimberleyensis

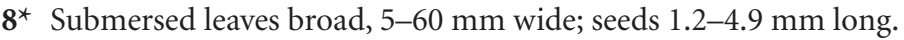

9. Fruit oval and thick-coated; seed coat closely adhering to embryo and difficult to detect, or tightly-fitting and very thin; floating leaves rarely formed. 10

9* Fruit elliptic and papery; seeds with a loose outer coat, easily separated from embryo; floating leaves commonly formed. 11

10. Perianth segments spathulate; south of the Tropic.

A. elongatus

$10 \star$ Perianth segments cuneate; north of the Tropic.

A. cuneatus

11. Seeds with a distinct knob at one end, cylindrical to narrowly elliptic, $0.7-1.6 \mathrm{~mm}$ wide.

A. vanbruggenii

$11^{\star}$ Seeds without a knob at one end, broadly elliptic to almost cylindrical, nearly oval, (1.1-) $1.5-2.8 \mathrm{~mm}$ wide.

12. Seeds broadly elliptic, $2-2.8 \mathrm{~mm}$ wide; Kimberley Region.

A. euryspermus

$12^{\star}$ Seeds almost cylindrical to narrow elliptical, $1.5-2 \mathrm{~mm}$ wide; eastern Northern Territory.

A. tofus

${ }^{\star}=$ introduced species

Aponogeton cuneatus S.W.L.Jacobs sp. nov.

A. elongato similis sed segmentis perianthii cuneatis, distributione geographica tropica differt.

Holotype. Queensland: Mowbray River, S of Port Douglas, $16^{\circ} 33.844^{\prime} \mathrm{S} 145^{\circ} 22.596^{\prime} \mathrm{E}$, S.W.L. Jacobs 9319 \& C.B. Hellquist, 15 Apr 2005 (NSW). Isotypes: BRI, NASC. 
Submersed aquatic perennial. Tuber ovate to elongate, to $4 \mathrm{~cm}$ long, $1.5 \mathrm{~cm}$ wide. Leaves submersed and rarely floating; submersed blades narrow to broadly-elliptic to elongate, $10-50 \mathrm{~cm}$ long, $2-5 \mathrm{~cm}$ wide, green or dark green to maroon-green; margins sometimes slightly undulate; base tapering gradually into petiole, sometimes asymmetrical; apex blunt-cuneate or obtuse; 5-9-veined; 0-2(-4) rows of lacunae on each side of the midrib; petiole to $30 \mathrm{~cm}$ long. Floating leaves not seen. Peduncle to c. $90 \mathrm{~cm}$ long, 2-4 $\mathrm{mm}$ wide at base broadening to 5-6 $\mathrm{mm}$ wide at base of inflorescence. Spathe to $1.5 \mathrm{~cm}$ long, caducous. Inflorescence yellow, emergent or floating, single, tightly-flowered or spaced along the rachis; rachis 1.1-3.1 mm wide. Flowers turned in all directions. Perianth segments 2, cuneate, 1-veined, yellow, 1-1.4 mm long, 1.4-2 mm wide. Stamens 6; anthers $0.3-0.4 \mathrm{~mm}$ long, $0.3-0.6 \mathrm{~mm}$ wide; filaments $0.8-1.7(-2.7) \mathrm{mm}$ long, broader at base. Carpels (2-)3(-6). Fruit rounded, thickcoated, 2.5-5.8 mm long, 1.8-5.0 mm wide; beak mostly lateral, occasionally terminal, to $1.5 \mathrm{~mm}$ long. Seeds $2-5$ per fruit, $1.2-3.2(-4.2) \mathrm{mm}$ long, $0.5-1.1(-1.6) \mathrm{mm}$ wide, elliptic, with a single testa, closely adhering to embryo or very thin.

Distribution: coastal Queensland north of the tropic.

Selected specimens examined: Queensland: Portland Roads Road between Tozers Gap and the Middle Claudie Crossing, Clarkson 2923, 25 Feb 1980 (DNA, MEL); McIvor R., N of HopevaleCooktown rd, Jacobs 8195, Hellquist \& Wiersma, 1 Aug 1997 (NSW, BRI, NASC); Stone Creek, nr Innisfail, Jacobs 8571 \& Les, 18 Oct 1999 (NSW, CONN).

Notes: permanent creeks and rivers, often shaded.

This species is named for the cuneate perianth segments characteristic of the species.

A. cuneatus is superficially similar to A. elongatus, but presents a gestalt that always made us suspect that it was a different taxon. No clear distinction could be made with seed characters so it was retained in A. elongatus. The use of comparative DNA sequence data (Les et al. 2005) indicated that, despite its superficial resemblance, A. cuneatus is quite distantly related to A. elongatus and actually most closely related to A. queenslandicus. Subsequently, better spirit collections have allowed us to see that a conspicuous difference exists in the shape of the perianth segments, with A. cuneatus having cuneate tepals (perianth segments) and A. elongatus having spathulate tepals.

\section{Aponogeton tofus S. W.L.Jacobs sp. nov.}

Aponogeton elongatus forma strigosus H. Bruggen (1969: 133). syn. nov.

Holotype. Northern Territory: Edith Falls Road, c. 3 miles [5 km] E of Stuart Highway, L.G. Adams 1658 (L). Isotype NSW.

A. euryspermo et A. vanbruggenii similis,sed ab A. euryspermo seminibus angustioribus cylindricis differt: ab A. vanbruggenii seminibus extremo etoruloso differt.

Holotype. Northern Territory: Cultivated by Dave Wilson, Howard Springs, $12^{\circ} 30.982^{\prime} \mathrm{S} 131^{\circ} 03.239^{\prime} \mathrm{E}, \mathrm{S}$. Jacobs 9258, 13 Mar 2005, originally from $100 \mathrm{~m}$ downstream ( $\mathrm{S}$ side) of the crossing of the Bulman to Gove rd over the Goyder River, $13^{\circ} 01.68^{\prime} \mathrm{S} 134^{\circ} 58.6^{\prime} \mathrm{E}$ (NSW).

Rooted, submersed perennial aquatic. Tuber ovate-elongate, 1-3 cm long, 1-2 cm wide. Leaves mostly submersed, sometimes floating. Submersed blades linear, linearlanceolate, ovate, or elliptic, to $23(-35) \mathrm{cm}$ long, $(0.5-) 1.4-2.5(-6) \mathrm{cm}$ wide; margins flat or slightly undulate; base narrowly to broadly cuneate, obtuse or attenuate; apex 
obtuse, broadly obtuse, blunt-cuneate to acute-cuneate, truncate, or rarely retuse; (3-)7-9(-11)-veined; 1-5 rows of lacunae on each side of midvein; petiole to $23(-50) \mathrm{cm}$ long. Floating leaves ovate or elliptic, to $11 \mathrm{~cm}$ long, green to maroon-green; margins flat; base cuneate, obtuse or attenuate; apex obtuse; midrib with 2-4 parallel veins on both sides; petiole to $64 \mathrm{~cm}$ long. Peduncle to $29(-107) \mathrm{cm}$ long, $0.6-1.8 \mathrm{~mm}$ wide at base broadening to (7-)22-48 $\mathrm{mm}$ wide at base of infloresence. Spathe to $1.5 \mathrm{~cm}$ long, caducous. Inflorescence yellow, emergent or floating, single, rarely branched, to c. $17 \mathrm{~cm}$ long, tightly flowered or spread out along rachis; rachis 0.9-3 $\mathrm{mm}$ wide. Flowers turned in all directions. Perianth segments 2, spathulate, 1-veined, yellow, c. $1.5 \mathrm{~mm}$ long, $0.7-1.5 \mathrm{~mm}$ wide. Stamens 6; anthers c. $0.2-0.5 \mathrm{~mm}$ long, 0.4-0.5 mm wide; filaments $1.2-2.1 \mathrm{~mm}$, broader at base. Carpels (2-)3. Infructescence moderately dense. Fruit 4-6 mm long, 3.3-4 mm wide, beak to $1 \mathrm{~mm}$ long, lateral, reflexed or straight. Seeds cylindrical, almost ovoid, $2-5$ per fruit, usually 1 per small fruit, 3.5-4.5 mm long, (1.1-)1.5-2 mm wide, thick outer testa easily removed, a second, if present, tightly adhering and difficult to remove.

Distribution: northern portion of the Northern Territory and Arnhem Land.

Selected specimens examined: Northern Territory: Edith Falls rd, c. 3 miles [5 km] E of Stuart Hwy, Adams 165811 Dec 1966 (NSW); c. 7 km NE Katherine on the Katherine River, Jacobs 3810 3 May 1980 (NSW); Cultivated by L. Smith, Kelso, Qld, Jacobs 8268 \& Hellquist, 18 Aug 1997, originally from the Northern Territory (NSW).

The following specimens were identified as A. euryspermus in Hellquist and Jacobs (1998) and almost certainly belong here, but the specimens have not been reannotated. Arnhem Land, Mt Gilruth area, $13^{\circ} 03^{\prime} \mathrm{S}, 133^{\circ} 01^{\prime} \mathrm{E}$, Henshall 1869, 6 Jun 1978 (DNA, MEL); lagoon at Jabiru, $12^{\circ} 40^{\prime} \mathrm{S}, 132^{\circ} 53^{\prime} \mathrm{E}$, Craven 2277, 17 Feb 1973 (DNA, MEL); Kakadu Nat. Park, 13 32'S, $132^{\circ} 29^{\prime}$ Russell-Smith 8559, 7 Jan 1992 (DNA).

Notes: grows in freshwater streams, rivers and lagoons, usually in or near sandstone country, especially the Arnhem Land Plateau. Flowering and fruiting December to February and May to July.

This species is named for the sandstone of the Arnhem Land Plateau area where most of the specimens have been collected. 'Tofus' is literally translated as 'tufa', which in modern usage is applied to a relatively porous or spongy rock composed of chemically or biologically precipitated $\mathrm{CaCO}_{3}$. In older usage, and Latin, 'tufa' (or tofus) was used for a sedimentary rock deposited in layers, a definition including sandstone.

Many specimens of Aponogeton from the tropics originally were assigned to A. elongatus by Bruggen (1985) and others but can now be assigned to A. euryspermus, A. vanbruggenii or $A$. tofus. These taxa initially produce submerged leaves in flowing or clear water but later in the year plants often develop floating leaves. Species in this group can be separated by their seed shape and size; A. euryspermus has large broad seeds that can become very thick when mature, $A$. tofus has narrower almost cylindrical seeds, while $A$. vanbruggenii has even narrower seeds with a distinct knob at one end. All have seeds with an outer testa that is easily removed (thick in A. euryspermus and A. tofus - thin in A. vanbruggenii). All species are confined to the tropics with A. euryspermus more westerly in its distribution, $A$. vanbruggenii more easterly and $A$. tofus growing between the two but overlapping with $A$. vanbruggenii. DNA sequence data (Les et al. 2005) indicate that indeed, A. tofus is closely related to A. euryspermus (as it had been previously identified); however, it is distinct and quite divergent at the molecular level from that and other species. 
Aponogeton elongatus F.Muell. ex Benth., Fl. Austr. 7: 188 (1878)

Submersed aquatic perennial. Tuber ovate to elongate, to $4 \mathrm{~cm}$ long, $1.5 \mathrm{~cm}$ wide. Leaves submersed and rarely floating (except for subsp. fluitans); submersed blades narrow to broadly-elliptic to elongate, $7-34(-42) \mathrm{cm}$ long, $0.8-3.7(-6.7) \mathrm{cm}$ wide, green or dark green to maroon-green; margins slightly undulate to undulate; base tapering gradually into petiole, broadly cuneate, obtuse, or rarely truncate, sometimes slightly asymmetrical; apex blunt-cuneate or obtuse; (5-)7-9(-11)-veined; $0-2(-4)$ rows of lacunae on each side of the midrib; petiole to $17(-35) \mathrm{cm}$ long. Floating leaves not commonly formed, narrowly elliptic to slightly obovate, 9-19 cm long, 2.2-3.5 cm wide; base obtuse, broadly cuneate, cordate, or truncate; apex obtuse; 7-9-veined; petiole to 60(-90) cm long. Peduncle to c. $90 \mathrm{~cm}$ long, 6-8 $\mathrm{mm}$ wide at base broadening to $5-8 \mathrm{~mm}$ wide at base of inflorescence. Spathe to $1.5 \mathrm{~cm}$ long, caducous. Inflorescence yellow, emergent or floating, single, tightly-flowered or spaced along the rachis; rachis 1.1-3.1 mm wide. Flowers turned in all directions. Perianth segments 2, spathulate, 1-veined, yellow, 1.8-2.5 mm long, 0.7-1.3 mm wide. Stamens 6; anthers $0.3-0.4 \mathrm{~mm}$ long, $0.3-0.6 \mathrm{~mm}$ wide; filaments $0.8-1.7(-2.7) \mathrm{mm}$ long, broader at base. Carpels (2-)3(-6). Fruit rounded, thick-coated, 2.5-5.8 mm long, 1.8-5.0 mm wide; beak mostly lateral, occasionally terminal, to $1.5 \mathrm{~mm}$ long. Seeds $2-5$ per fruit, 1.2-3.2(-4.2) mm long, 0.5-1.1(-1.6) $\mathrm{mm}$ wide, elliptic, with a single testa, closely adhering to embryo or very thin.

Distribution: coastal Queensland south of the Tropic and coastal northeastern New South Wales.

1. Plants rarely or never producing floating leaves ................................... 10a. subsp. elongatus

$1^{\star}$ Plants commonly producing floating leaves 10b. subsp. fluitans

\section{Aponogeton euryspermus Hellq. \& S.W.L.Jacobs, Telopea 8: 16 (1998)}

Rooted, submersed perennial aquatic. Tuber ovate-elongate, to $1-3 \mathrm{~cm}$ long, 1-2 cm wide. Leaves submersed and/or floating. Submersed blades linear, linear-lanceolate, ovate, or elliptic, to $23(-35) \mathrm{cm}$ long, (0.5-)1.4-2.5(-6) $\mathrm{cm}$ wide; margins flat or slightly undulate; base narrowly to broadly cuneate, obtuse, or attenuate; apex obtuse, broadly obtuse, blunt-cuneate to acute-cuneate, truncate, or rarely retuse; (3-)7-9 (-11)-veined; $1-5$ rows of lacunae on each side of midvein; petiole to $23(-50) \mathrm{cm}$ long. Floating leaves ovate or elliptic, to $11 \mathrm{~cm}$ long, green to maroon-green; margins flat; base cuneate, obtuse, or attenuate; apex obtuse; midrib with 2-4 parallel veins on both sides; petiole to $64 \mathrm{~cm}$ long. Peduncle to $29(-107) \mathrm{cm}$ long, $0.6-1.8 \mathrm{~mm}$ wide at base broadening to (7-)22-48 mm wide at base of inflorescence. Spathe to $1.5 \mathrm{~cm}$ long, caducous. Inflorescence yellow, emergent or floating, single, rarely branched, to c. $17 \mathrm{~cm}$ long, tightly flowered or spread out along rachis; rachis $0.9-3 \mathrm{~mm}$ wide. Flowers turned in all directions. Perianth segments 2, spathulate, 1-veined, yellow, 1.1-2 mm long, 0.7-1.5 mm wide. Stamens 6; anthers c. $0.2-0.5 \mathrm{~mm}$ long, $0.4-0.5 \mathrm{~mm}$ wide; filaments $1.2-2.1 \mathrm{~mm}$, broader at base. Carpels (2-)3. Infructescence moderately dense. Fruit 3-6.2 mm long, 2.4-5 mm wide, beak to $1 \mathrm{~mm}$ long, terminal or lateral, reflexed or straight. Seeds broadly elliptic, almost ovoid,1-3(-4) per fruit, usually 1 per small fruit, 3.2-4.4 mm long, (1.1-)2-2.8 mm wide, thick outer testa easily removed, a second, if present, tightly adhering and difficult to remove.

Distribution: the Kimberley Region of Western Australia. 


\section{Acknowledgments}

We thank Karen Wilson for the Latin diagnoses, and Dave Wilson for continued cooperation by collecting and cultivating specimens.

\section{References}

Bruggen HWE van (1969) Revision of the genus Aponogeton (Aponogetonaceae): III. The species of Australia. Blumea 17: 121-137.

Hellquist CB \& Jacobs SWL (1998) Aponogetonaceae of Australia with descriptions of six new taxa. Telopea 8: 7-19.

Les DH, Moody ML \& Jacobs SWL (2005) Phylogeny and systematics of Aponogeton (Aponogetonaceae): the Australian species. Systematic Botany 30: 503-519.

Submitted 20 September 2005, accepted 07 December 2005 